\title{
FAKTOR-FAKTOR YANG BERHUBUNGAN DALAM PENGELOLAAN OBAT ATAU OBAT TRADISIONAL UNTUK PENGOBATAN SENDIRI DI MASA PANDEMI
}

\author{
Affecting Factors In The Management Of Drug Or Traditional Medicines For Self- \\ Medication In Pandemic Times
}

\section{Melviani ${ }^{\text {I* }}$ \\ Rohama $^{2}$}

1,2, Health Faculty, Sari Mulia University, Banjarmasin City, South Borneo 70238, Indonesia

*email: melviani.apt87@gmail.com

\begin{abstract}
Abstrak
Swamedikasi atau pengobatan sendiri adalah kegiatan atau tindakan mengobati diri sendiri dengan obat tanpa resep secara tepat dan bertanggung jawab. Keterbatasan kegiatan dan aktivitas yang disebabkan pandemi COVID-19 akhirnya menyebabkan terbatasnya kegiatan pelayanan kesehatan. Masyarakat yang mempunyai keluhan sakit merasa lebih waspada untuk memeriksakan keadaanya ke tenaga medis sehingga memilih untuk melakukan pengobatan mandiri. Tujuan dari penelitian ini adalah mengetahui faktor-faktor yang berhubungan dalam pengelolaan obat dan obat tradisonal untuk pendekatan analitik secara mandiri di masa pandemi covid-I9. Penelitian ini bersifat deskriptif. Sampel dalam penelitian ini berjumlah II3 orang dengan teknik convenience sampling. Hasil faktor yang berhubungan berdasarkan penelitian diketahui bahwa pengelolaan obat dan obat tradisional secara mandiri berhubungan oleh jenis kelamin, pekerjaan, dan jarak tempat membeli, diperoleh dengan nilai $P \quad 0,000 \quad(<0,05)$ berdasarkan uji statistik faktor-faktor yang berhubungan pengelolaan obat baik sebelum pandemi maupun sesudah pandemi yang artinya ada hubungan yang bermakna antara penggunaan obat baik sebelum pandemi maupun sesudah pndemi dengan jenis kelamin, pekerjaan, dan jarak tempat membeli.
\end{abstract}

\section{Kata Kunci:}

Faktor- faktor

Obat

Swamedikasi

\begin{abstract}
Self-medication or self-medication is the activity or act of self-medicating with medication without a proper and responsible prescription. Limited activities and activities caused by the COVID-I 9 pandemic eventually led to limited health care activities. People who have complaints of pain feel more vigilant to check the situation to medical personnel so choose to do independent treatment. The purpose of this study is to find out the factors that affect the management of traditional drugs and drugs independently in the covid-19 pandemic. This research is descriptive. The sample in this study amounted to II 3 people with convenience sampling techniques. The results obtained based on research are known that the management of drugs and traditional medicines independently is influenced by gender, occupation, and distance of place to buy, based on statistical tests of factors that affect drug management both before pandemic and after pandemic obtained a value of $p$ $0,000(<0,05)$, which means there is a meaningful relationship between drug use both before the pandemic and after the pademic with gender, work, and the distance from where to buy.
\end{abstract}

Medicine

Self-medication

(c) year The Authors. Published by Institute for Research and Community Services Universitas Muhammadiyah Palangkaraya. This is Open Access article under the CC-BY-SA License (http://creativecommons.org/licenses/by-sa/4.0/). DOI: https://doi.org/10.33084/jsm.vxix.xxx.

\section{PENDAHULUAN}

Swamedikasi atau pengobatan sendiri adalah kegiatan atau tindakan mengobati diri sendiri dengan obat tanpa resep secara tepat dan bertanggung jawab. Banyaknya masyarakat yang melakukan swamedikasi dikarenakan adanya informasi mengenai iklan obat bebas dan obat bebas terbatas. Obat-obatan yang dijual di pasaran memudahkan seseorang untuk melakukan swamedikasi terhadap keluhan penyakitnya, karena relatif lebih cepat, hemat biaya dan praktis tanpa perlu periksa ke dokter. Namun, untuk melakukan swamedikasi diperlukan informasi yang benar agar dapat dicapai mutu swamedikasi yang baik, yaitu tersedianya obat yang cukup dengan informasi yang memadai akan 
meningkatkan derajat kesehatan masyarakat (Melviani, et al., 202l).

Obat-obat tradisional juga menjadi pemakaian yang banyak digunakan oleh masyarakat di masa pandemi karena banyaknya penelitian yang membuktikan secara ilmiah (Noval, et al., 2021). Maka dari itu pemakaian ini perlu dibarengi oleh informasi yang diberikan secara jelas agar masyarakat mendapatkan pengetahuan tentang obat yang mereka gunakan (Noval, et al., 2020).

Perpres No 12 tahan 2013 pasal 43 mengamanatkan bahwa dalam rangka kendali mutu dan kendali biaya, Menteri Kesehatan bertanggung jawab untuk penilaian teknologi kesehatan. Biaya kesehatan tahunan di Indonesia terus mengalami peningkatan selama satu dekade terakhir, sehingga pengendalian biaya dilakukan guna mencapai cost-effectivenes. Pada masa Covid-19 berdampak kepada kehidupan sosial dan melemahnya ekonomi masyarakat terutama dalam bidang Kesehatan (Melviani \& Budi, 2019).

\section{METODOLOGI}

Penelitian ini menggunakan rancangan penelitian observasional dengan pendekatan cross-sectional. Survei berbasis komunitas dilakukan terhadap sejumlah responden di Kota Banjarmasin.

Cara pengambilan subyek dalam penelitian ini diseleksi secara convenience sampling (Fernandez et al., 2014) yaitu dengan pertimbangan kemudahan, siapa saja yang ditemui baik secara tidak sengaja atau kebetulan bertemu dengan peneliti, dapat digunakan sebagai sampel dengan memperhatikan orang/calon responden tersebut sesuai sebagai sumber data dan sesuai dengan kriteria dalam penelitian ini. Analisis data yang dilakukan dalam penelitian yang diperoleh akan dianalisis dengan program IBM SPSS Statistic 16 meliputi analisis secara deskriptif dan analitik statistik bivariat dan multivariat. Pengambilan sampel penelitian menggunakan teknik stratified multistage cluster dengan memperhatikan lokasi geografis yang dikelompokkan menurut Badan Pusat Statistik (BPS). Perhitungan besar sampel dalam penelitian ini adalah sebanyak I I3 responden.

Jenis data yang digunakan pada penelitian ini adalah jenis data kuantitatif. Data primer pada penelitian ini diperoleh dari mengajukan pertanyaan kepada responden melalui kuisioner dengan melalui Google Form.

Data sekunder yang digunakan peneliti adalah data yang bisa mendukung informasi primer yang telah diperoleh pada penelitian yaitu dari bahan pustaka, literatur, penelitian yang terdahulu, buku, dan lain sebagainya. Pada penelitian ini Instrumen adalah kuesioner melalui Google form yang dibuat oleh peneliti.

\section{HASIL DAN PEMBAHASAN}

Penelitian untuk pengambilan data dilakukan pada bulan Maret - April 202I di Kota Banjarmasin

Tabel I. Karakteristik responden

\begin{tabular}{lll}
\hline $\begin{array}{l}\text { Kategori Karakteristik } \\
\text { Responden }\end{array}$ & Jumlah (n) & f (\%) \\
\hline Jenis Kelamin & 78 & 69 \\
\hline Laki-Laki & 35 & 31 \\
Perempuan & & \\
\hline Pekerjaan & 78 & 69 \\
\hline Bekerja & 35 & 31 \\
Tidak Bekerja & & \\
\hline Pendidikan & 10 & 8.8 \\
\hline SD Sederajat & 15 & 13.3 \\
SMP Sederajat & 19 & 16.8 \\
D3 & 69 & 61.1 \\
SI/S2 & & 69 \\
\hline Status dalam keluarga & & 31 \\
\hline Kepala Keluarga & 78 & 16.8 \\
Bukan Kepala Keluarga & 35 & 13.3 \\
\hline Pendapatan & & \\
\hline <Rp. 500.000 & 10 & \\
Rp. 500.000-Rp. I.000.000 & 15 & \\
Rp. 2.500.000-Rp. & 19 & \\
5.000 .000 & & \\
>Rp. 5.000.000 & 69 & \\
\hline Pengeluaran & & \\
\hline
\end{tabular}




\begin{tabular}{lll}
\hline <Rp. 500.000 & 10 & 8.8 \\
Rp. $500.000-$ Rp. 1.000 .000 & 15 & 13.3 \\
$\begin{array}{l}\text { Rp. } 2.500 .000-\text { Rp. } \\
\text { 5.000.000 }\end{array}$ & 19 & 16.8 \\
$>$ Rp. 5.000 .000 & 69 & 61.1 \\
\hline
\end{tabular}

Hasil validitas yang sudah didapatkan tersebut maka dapat disimpulkan bahwa 47 pertanyaan yang diajukan kepada responden dapat dikatakan valid karena nilai $r$ hitung lebih besar daripada nilai $r$ tabel. Hasil uji reliabilitas pada tabel di atas maka dapat dilihat bahwa nilai Cronbach Alpha adalah 0.835 yang menunjukkan bahwa ke-47 pertanyaan memiliki reliabilitas yang tinggi artinya jika pertanyaan tersebut dilakukan untuk beberapa kali yang digunakan untuk mengukur obyek yang sama maka akan menghasilkan data yang sama.

Responden laki-laki akan lebih banyak terlibat dalam penggunaan obat baik untuk dirinya maupun untuk keluarga dibandingkan dengan responden perempuan (Fauddah, 20I5). Menurut Thomas (20II), laki-laki akan lebih peduli terhadap kesehatan dirinya terutama keluarganya dibandingkan dengan perempuan, hal ini sudah sesuai dengan hasil yang didapatkan pada penelitian ini dimana responden yang bersedia untuk berpartisipasi pada penelitian ini adalah laki-laki. Dari hasil penelitian dilihat bahwa lebih banyak jumlah orang yang sudah memiliki pekerjaan dari pada yang tidak memiliki pekerjaan. Menurut Rinda (2014) jenis pekerjaan seseorang dapat berhubungan tingkat sosial dan interaksi antar individu akibat lingkungan yang berbeda.

Pendidikan adalah sebuah proses mengembangkan kemampuan dan usaha mendewasakan kepribadian melalui upaya pengajaran dan pelatihan (Notoatmodjo, 20I2). Tingkat Pendidikan berperan dalam menentukan mudah tidaknya seseorang menyerap dan memahami pengetahuan yang mereka peroleh. kepedulian seseorang terhadap Kesehatan pribadinya dapat berhubungan oleh tingkat Pendidikan yang semakin tinggi.
Pendapatan seseorang memiliki peran yang penting dimana pendapatan dapat berhubungan keputusan dalam konsumsi obat. Menurut simamora (2004) yang mengatakan bahwa pendapatan sangat berhubungan dalam memilih produk yang akan dikonsumsi. Persentase tertinggi adalah responden yang memiliki pendapatan rata - rata >Rp. 5.000.000 dengan persentase $61.1 \%$ dan pengeluaran tertinggi juga rata rata >Rp. 5.000 .000 dengan persentase 61.1\%.

Tabel 2. Faktor-Faktor Yang Berhubungan Dengan Penggunaan Obat Sebelum Pandemi

\begin{tabular}{cccc}
\hline No & Faktor & $\begin{array}{c}\text { Nilai } \mathbf{p} \\
(<\mathbf{0 , 0 5})\end{array}$ & Keterangan \\
\hline I. & Jenis Kelamin & 0,000 & $\begin{array}{c}\text { Memiliki } \\
\text { Hubungan }\end{array}$ \\
\hline 2. & Pekerjaan & 0,000 & $\begin{array}{c}\text { Memiliki } \\
\text { Hubungan }\end{array}$ \\
\hline 3. & Jarak & 0,000 & $\begin{array}{c}\text { Memiliki } \\
\text { Hubungan }\end{array}$ \\
\hline
\end{tabular}

Tabel 3. Faktor-Faktor Yang Berhubungan Dengan Penggunaan Obat Sesudah Pandemi

\begin{tabular}{|c|c|c|c|}
\hline No & Faktor & Nilai $p(<0,05)$ & Keteragan \\
\hline $\mathrm{I}$. & $\begin{array}{c}\text { Jenis } \\
\text { Kelamin }\end{array}$ & 0,000 & $\begin{array}{l}\text { Memiliki } \\
\text { Hubungan }\end{array}$ \\
\hline 2. & Pekerjaan & 0,000 & $\begin{array}{l}\text { Memiliki } \\
\text { Hubungan }\end{array}$ \\
\hline 3. & Jarak & 0,000 & $\begin{array}{l}\text { Memiliki } \\
\text { Hubungan }\end{array}$ \\
\hline
\end{tabular}

Dari hasil penelitian tersebut dapat disimpulkan adanya hubungan bermakna antara konsumsi obat pada masyarakat dengan jarak tempat pembelian obat baik sebelum maupun saat masa pandemi.

Hasil ini didukung dengan penelitian (Yollanda,20I8) yang menyatakan aksesibilitas (keterjangkauan pelayanan) berpengaruh pada keputusan masyarakat untuk mendapatkan pelayanan kesehatan. Namun hasil ini tidak sejalan dengan penelitian (Adi,2019) dimana menyatakan lokasi pembelian obat tidak selalu berhubungan keputusan masyarakat dalam pembelian obat. Hal ini dikarnakan masyarakat memlikiki tempat langganannya masing-masing. 
Dari hasil ini dapat dilihat jarak berhubungan masyarakat dalam membeli obat dan selanjutnya akan digunakan, walaupun beberapa orang memiliki tempat langganannya sendiri dalam membeli obat. Tapi dalam saat yang mendadak memerlukan obat masyarakat tentu akan memilih tempat yang paling dekat degan keberadaannya.

Pekerjaan berpengaruh pada keputusan masyarakat pada penggunaan obat, baik sebelum maupun saat masa pandemi. Hasil ini didukung penelitian (Yollanda,2018) yang menyatakan bahwa pekerjaan berpengaruh pada keputusan masyarakat memperoleh layanan kesehatan. Masyarakat yang tidak memiliki pekerjaan cenderung mendatangi puskesmas untuk mendapatkan obat. Sedangkan tenaga kesehatan pastinya memerlukan banyak suplemen setiap harinya untuk menjaga tubuh tetap vit dan bugar selama masa pandemi. Pekerjaan juga berpengaruh pada pendapatan. penelitian (Ismail,20I5) menunjukkan, masyarakat dengan pendapatan dengan dana yang cukup saat sakit dapatpilihan pertama pastilah mengunjungi dokter dan mendapatkan obat obatan modern. Sebaliknya dengan masyarakat dengan dana yang kurang mencukupi, mereka cenderung mengonsumsi ramuan obat tradisional dengan harga yang lebih terjangkau.

Jenis kelamin berhubungan dalam penggunaan obat baik sebelum maupun setelah masa pandemi. Hal ini didukung oleh penelitian Cho et al (2013) menyatakan jenis kelamin berhubungan penggunaan obat, dimana perempuan dan orang tua mempunyai penyakit kronis lebih sering melakukan pengobatan sendiri. Menurut (Wulandari, 2014) Perempuan mengonsumsi suplemen penambah darah seperti zat besi, asam folat, riboflavin, dll untuk mencegah anemia. Menurut (Swamilaksita, 2016) Suplemen lebih juga diperlukan untuk ibu hamil seperti zat besi, asam folat, vitamin $A$, vitamin $C$ dan zink untuk meningkatkan hasil kehamilan atau memper-tahankan zat gizi dalam tubuh selama kehamilan. Hal ini menandakan adanya hubungan penggunaan obat dengan jenis kelamin berdasarkan kebutuhannya masing-masing.

Pada masa pandemi masyarakat cenderung menggunakan lebih banyak obat-obatan berupa suplemen. Sejalan dengan hal ini menurut penelitian (nurbaety,202I) pada masa pandemi haruslah menjaga tubuh tetap sehat dan memiliki imun yang kuat. Hal ini dapat dilakukan dengan mengonsumi suplemen atau vitamin untuk penambah daya tahan tubuh, seperti vitamin $C$ dan multivitamin yang mengandung zat besi, untuk mencegah penularan virus corona.

Obat-obatan yang dijual di pasaran memudahkan seseorang untuk melakukan swamedikasi terhadap keluhan penyakitnya, karena relatif lebih cepat, hemat biaya dan praktis tanpa perlu periksa ke dokter. Namun, untuk melakukan swamedikasi diperlukan informasi yang benar agar dapat dicapai mutu swamedikasi yang baik, yaitu tersedianya obat yang cukup dengan informasi yang memadai akan meningkatkan derajat kesehatan masyarakat.

Berdasarkan hasil penelitian didapatkan bahwa tempat membeli obat maupun obat tradisional mayoritas membeli obat di apotek yaitu sebesar 69\% (78 orang). Sejalan dengan penelitian Siahaan dkk., (2017) bahwa apotek merupakan tempat terbaik untuk membeli obat, baik itu obat keras, obat bebas, vitamin maupun suplemen. Berdasarkan data Badan Pusat Statistik Kalimatan Selatan tahun 2018, di kawasan Kota Banjarmasin terdapat 123 apotek. Jumlah apotek yang cukup banyak tersebut menyebabkan mudahnya menemukan apotek di kawasan Kota Banjarmasin, kemudahan tersebut diasumsikan menjadi alasan besarnya pembelian obat di apotek oleh masyarakat.

Pada penelitian ini jenis obat yang digunakan responden sebanyak 6I,I\% (69 orang) obat modern dan penggunaan obat tradisional sebesar 38,9\% (44 orang). Berdasarkan hasil penelitian bentuk sediaan yang paling banyak digunakan adalah pil sebanyak 61,1\% (69 orang) sedangkan untuk obat tradisional masyarakat yang menggunakan bagian herba 47,7\% (2I 
orang) serta bagian tanaman yang digunakan buah 43,3\% (19 orang) dan juga cara pengolahannya adalah direbus $56,8 \%$ (25 orang). Bentuk sediaan obat tertentu dipilih demi kenyamanan serta meningkatkan compliance dan tercapainya keberhasilan terapi (Wiedyaningsoh dkk., 2004).

Pada penelitian ini sebanyak 48,7\% (55 orang) telah mengetahui cara penggunaan obat yang baik dan benar. Sejalan dengan penelitian Wisely, bahwa sebayak 92,82\% responden menyatakan bahwa mereka mengkonsumsi obat sesuai dengan dengan anjuran yang ada pada kemasan yang telah mereka baca, mereka menganggap bahwa konsumsi obat sesuai dengan anjuran merupakan hal yang penting sebab kekeliruan dalam penggunaan obat dapat memberikan dampak yang merugikan. Berdasakan hal tersebut maka diasumsikan responden mengetahui cara konsumsi obat yang baik dan benar (Wisely, 2008)

Berdasarkan karakteristik pengetahuan mengenai cara penyimpanan obat yang baik, sebanyak 54,9\% (40 orang) menjawab mengetahui. Melanjutkan terkait pengetahuan penyimpanan, sebanyak $25,4 \%$ (40 orang) menyatakan bahwa obat disimpan dalam wadah tertutup baik.

Zat berkhasiat dalam obat selalu mempunyai masa aktif untu tujuan pengobatan, biasanya masa aktif tersebut tertulis pada lembar informasi. Sebanyak 54,9\% (62 orang) responden menyatakan bahwa mereka memperhatikan tanggal kadaluarsa obat. Sejalan dengan Fajrin dalam penelitiannya bahwa 100\% responden memperhatikan masa kadaluarsa obat yang tertera pada kemasan obat. Namun, pada penelitian tersebut tidak ada satupun responden yang mengetahui batas waktu penyimpanan obat setelah wadahnya dibuka untuk pertama kalinya (Fajrin dkk., 2019). Dari hasil penelitian, sebanyak $39,8 \%$ (44 orang) responden mencari infomasi mengenai cara pembuangan yang benar.

Obat yang sudah kadaluarsa atau rusak harus segera dibuang. Cara pembuangan obat ini tidak boleh sembarangan karena dikhawatirkan akan disalahgunakan oleh orang lain. Pembuangan obat yang benar adalah dengan ditimbun di tanah atau dibuang ke saluran air. Cara membuang kemasan obat jika wadah berupa botol atau pot plastik terlebih dahulu lepaskan etiket obat dan tutup botol kemudian dibuang di tempat sampah, untuk boks/ dus/ tube digunting dahulu baru dibuang (Heni dkk, 2017).

\section{KESIMPULAN}

Pandemi global Covid-19 membuat kita mengalami perubahan yang cukup luar biasa, tidak terlepas pada masyarakat Banjarmasin, Kalimantan Selatan. Pandemi ini menyebabkan seluruh kegiatan manusia terbatas tidak terkecuali mengenai kegiatan pelayanan kesahatan. Oleh karena itu, masyarakat yang mempunyai keluhan sakit saat masa pademi merasa lebih waspada untuk memeriksakan kondisinya ke tenaga medis di fasilitas pelayanan kesehatan. Pengobatan mandiri atau swamedikasi akhirnya menjadi pilihan masyarakat dalam memenuhi pengobatannya untuk mencapai keadaan sehat. Pengelolaan dan penggunaan obat dan obat tradisional baik di sebelum pandemi maupun sesudah pandemi berhubungan secara bermakna oleh jenis kelamin, pekerjaan, dan jarak tempat pembelian obat.

\section{UCAPAN TERIMA KASIH}

Penulis mengucapkan terimakasih kepada DITJEN DIKTI atas bantuan biaya pada skim Penelitian Dosen Pemula (PDP) Tahun Pelaksanaan 2021.

\section{REFERENSI}

I. Melviani, M., Fricilia, O. Z., Peranginangin, I. M., Rachman, F. I., \& Munawarah, M. (202I). Gambaran Penggunaan dan Penyimpanan Obat oleh Masyarakat di Kota Banjarmasin Tahun 2020. Jurnal Surya Medika (JSM), 7(I), I23-I 27. 
2. Noval, N., Nugraha, D. F., Nastiti, K., Syahrina, D., \& Novia, N. (202I). Local Natural Product Development in the Era of Covid 19 Pandemic. Indonesia Berdaya, 2(2), I33-I 40.

3. Noval, N., Nastiti, K., Nugraha, D. F., Rahmadani, R., \& Alawiyah, T. (2020). PRODUK INOVASI HAND SANITIZER DARI AKAR BAIAKAH SEBAGAI UPAYA PENCEGAHAN DI MASA PANDEMI COVID-19. LOGISTA-Iurnal Ilmiah Pengabdian Kepada Masyarakat, 4(2), 305-3I2.

4. Budi, S. (2020). ANALISIS NILAI WILLINGNESS TO PAY PER QUALITY ADIUSTED LIFE YEAR TERAPI PENYAKIT MODERATE MASYARAKAT DI KOTA BANIARMASIN TAHUN 2019. Borneo Journal of Pharmascientech, 4(I), I-I I.

5. Badan Pusat Statistik Kota Banjarmasin. Kota Banjarmasin Dalam Angka 2020. Banjarmasin: BPS Kota Banjarmasin, 2020.

6. BPS Kota Banjarmasin. (20I8). Profil Tenaga Kerja Kota Banjarmasin 2018. Banjarmasin: Badan Pusat Statistik Kota Banjarmasin. ISBN 978-6026900-74-6.

7. Fajrin, A., Yuniarni, U., \& Suwendar. (20/9). Kajian Gambaran Pengetahuan Masyarakat Terhadap Penyimpanan Obat di Rumah di Kelurahan Babakan Sari Kota Bandung. Prosidining Farmasi, 5(2): 336-343.

8. Fatoni Siti Nur, Dkk. 2020. Dampak COVID-I9 Terhadap Perilaku Konsumen Dalam Penggunaan E-Wallet di Indonesia. UIN Sunan Gunung Djati: Bandung.

9. Fauddah, A., T., (20I5). Description of Self Medication Behavior in Community of Subdistrict Purbalingga, District Purbalingga. Jurnal Kesehatan Masyarakat. Kesehatan Masyarakat, Universitas Diponegoro. Vol 3 (I). hal 614, 617-618

10. Fernandez, Mercedes Rodriguez, et al. (20/4). Board characteristics and firm performance in Spain. The international journal of business in society, Corporate Governance, Vol. 14 Iss 4 pp. $485-503$.

II. Notoatmodjo. 2012. Metode Penelitian Kesehatan. Jakarta: Rineka Cipta.

12. Sayuti Rosiady Husaenic dan Stiti Aisyah Hidayati. 2020. Dampak Pandemi Covid-19 Terhadap Ekonomi Masyarakat di Nusa Tenggara Barat. Universitas Mataram.
13. Siahaan, S., Usia, T. Pujiati, S., dkk. (20/7). Pengetahuan, Sikap, dan Perilaku Masyarakat dalam Memilih Obat yang Aman di Tiga Provinsi di Indonesia. Jurnal Kefarmasian Indonesia, 7(2): |36-| 45.

14. Simamora, Herry. 2004. Manajemen Sumber Daya Manusia. Jakarta: Bumi Aksara

15. Thomas, (20II). Pengaruh Tingkat Pendidikan Terhadap Tingkat Pengetahuan Masyarakat Mengenai Antibiotika di Kecamatan Mergangsan Kota Yogyakarta, Skripsi. Universitas Sanata Dharma, Yogyakarta

16. Wisely. (2008). Studi Tentang Pemahaman Obat Tradisional Berdasarkan Informasi Pada Kemasan dan Alasan Pemilihan Jamu Ramuan Segar atau Jamu Instan Pada Masyarakat Desa Maguwoharjo. Skripsi. Yogayakarta: Fakultas Farmasi Universitas Sanata Dharma. 